\title{
Steer diets in a montane riparian community
}

\author{
ANDREW J. PELSTER, STEVEN EVANS, WAYNE C. LEININGER, M. J. TRLICA, AND WARREN P. CLARY
}

\begin{abstract}
Authors are Natural Resource Specialist, City of Boulder Open Space and Mountain Parks Department, 7315 Red Deer Dr., Boulder, Colo. $80301 ;$ Natural Resource Specialist, 19 Mile Ranch, Uvalde, Tex. 7880I; Professors, Forest, Rangeland and Watershed Stewardship Department, Colorado State University, Fort Collins, Colo. 80523; and Project Leader (retired), Rocky Mountain Research Station, 316 E. Myrtle St., Boise, Ida. 83702.
\end{abstract}

\section{Abstract}

Diets of fistulated steers that grazed a montane riparian community were determined throughout a growing season. The objective was to determine if willow (Salix spp.) consumption by steers was related to the season of use and the residual stubble heights of herbaceous forage species. Diet samples were collected at 4 levels of herbaceous utilization throughout 4 grazing periods that were based on willow phenology. Results suggested that spring grazing of riparian pastures was preferable to late-season use to minimize browsing on willows. Willow consumption increased substantially as herbaceous stubble height approached 10 and $18 \mathrm{~cm}$ during the spring and early-summer grazing periods, repectively. Stubble heights greater than $20 \mathrm{~cm}$ were needed to reduce willow consumption when they were most preferred during the late-summer and fall grazing seasons in this tall sedge (Carex spp.)/willow riparian community. Sedge and rush (Juncus spp.) composition in steer diets declined, while willow composition increased in steer diets, in response to decreasing stubble heights. Grass consumption by steers was little affected by stubble height, while forb consumption was directly related to forb availability. Although grazing activity has the potential to negatively impact riparian willows, these results suggested that timing of use and carefully controlled levels of herbaceous utilization could be used to minimize the consumption of willows by cattle in a montane riparian community.

Key Words: Carex spp., Salix spp., seasonal cattle diets, grazing management, utilization, stubble height

Riparian ecosystems are highly prized by wildlife managers, because of the structurally diverse habitat they provide (Kauffman and Krueger 1984, Elmore and Beschta 1987). At the same time, riparian ecosystems are important to livestock producers because of the abundant forage they furnish (Roath and Krueger 1982, Schulz and Leininger 1990). The general public has also become aware of the importance of riparian ecosystems, because of their high biodiverstiy (Belsky et al. 1999) and the high recreational potential found within these areas (Armour et al. 1994). Recent research has involved integrated programs designed to produce information that will guide resource managers toward improving the status of degraded riparian areas (Popolizio et al. 1994). However, in spite of recent research on riparian ecosystems, there is still little scientifically derived infor-

Research was funded by the USDA-CSREES Rangeland Research Grants Program, U.S. Forest Service Research Joint Venture Agreement, and Colorado State University Agricultural Experiment Station.

Manuscript accepted 21 Feb. 04

\section{Resumen}

Las dietas de novillos fistulados que apacentaron una comunidad ribereña montañosa se determinaron a través de la estación de crecimiento. El objetivo de este estudio fue determinar si el consumo de "Willow" (Salix spp.) por los novillos estaba relacionado con la época de uso y la altura del rastrojo remanente de las especies forrajeras herbáceas. Se colectaron muestras de la dieta a 4 niveles de utilización de la vegetación herbácea a través de 4 periodos de apacentamiento que fueron basadas en la fenología del "Willow". Los resultados sugieren que el apacentamiento en primavera de los potreros ribereños fue preferible sobre el uso a fines de estación para minimizar el ramoneo de los "Willow". El consumo de "Willow" se incremento substancialmente conforme la altura del rastrojo de la vegetación herbácea alcanzó 10 y $18 \mathrm{~cm}$ durante los periodos de apacentamiento de primavera e inicios de verano respectivamente. En esta comunidad ribereña de "Sedge altos" (Carex spp.)/'Willow" se necesitaron alturas del rastrojo mayores de 20 cm para reducir el consumo de "Willow" cuando fueron los mas preferidos durante las estaciones de fines de verano y otoño La composición de "Sedge" and "Rush" (Juncus spp.) disminuyó en la dieta de los novillos mientras que el consumo de "Willow" aumento en respuesta a la disminución de la altura del rastrojo. El consumo de zacates por los novillos fue poco afectado por la altura del rastrojo, mientras que el consumo de hierbas estuvo directamente relacionado con su disponibilidad. Aunque la actividad de apacentamiento tiene el potencial de impactar negativamente los "Willow" ribereños, estos resultados sugieren que la época de uso y niveles cuidadosamente controlados de la utilización de las herbáceas pudieran ser utilizados para minimizar el consumo de "Willow" por el ganado en una comunidad ribereña de montaña.

mation available for effective livestock management in these areas (Baker and Leininger 1992, Leonard et al. 1997, Mosley et at. 1997).

Although numerous studies have been conducted to investigate livestock distribution (Bryant 1982, Roath and Krueger 1982, Marlow and Pogacnik 1985, 1986, Pinchak et al. 1991, Clary and Booth 1993) and vegetation utilization (Kauffman et al. 1983, Platts and Nelson 1985, Schulz and Leininger 1990, Smith et al. 1992) within the riparian zone, few studies have directly addressed cattle diet selection (Huber et al. 1995) within these important ecosystems. In addition, data on how residual stubble height affects livestock diet selection within riparian areas is absent from the literature.

Willows (Salix spp.) contribute to the health of many riparian areas by stabilizing and facilitating the rebuilding of streambanks, 
and by providing food for aquatic animals and shade which moderates instream water temperatures (Kauffman and Krueger 1984). Unfortunately, this component of riparian vegetation structure is usually the first to be negatively impacted by poor livestock management (Schulz and Leininger 1990). However, degraded riparian areas can generally be restored through improved management practices (Chaney et al. 1993).

The overall objective of this study was to determine if willow consumption by cattle in a montane riparian zone was more closely related to the season of use (e.g. spring or fall) or to the residual stubble height of the herbaceous forage.

\section{Materials and Methods}

The study site was located within the Sheep Creek Grazing Allotment in north central Colorado, about $80 \mathrm{~km}$ northwest of Fort Collins. The Allotment is located within the Roosevelt National Forest at an elevation of approximately $2,500 \mathrm{~m}\left(40^{\circ}\right.$ $\left.56^{\prime} 70^{\prime \prime} \mathrm{N}, 105^{\circ} 40^{\prime} 18^{\prime \prime} \mathrm{W}\right)$. Sheep Creek is a 4 to $5 \mathrm{~m}$ wide stream and is classified according to Rosgen (1994) as a C-3 stream. Soils in the study area are from the Fluvaquents Series, derived from weathered granite, and have a sandy loam to clay loam texture (USDA 1980). There was a heavy organic $\mathrm{O}$ horizon as much as $20 \mathrm{~cm}$ thick in the study area.

Sheep Creek was heavily grazed by domestic livestock from the 1890's to 1956, at which time 3 large grazing exclosures were constructed by the U.S. Forest Service and the Colorado Division of Wildlife. These exclosures encompass 40 ha of riparian meadow along $2.5 \mathrm{~km}$ of stream (Schulz and Leininger 1990, Popolizio et al. 1994). Livestock grazing has been excluded within the exclosures since their construction in 1956.

Average annual precipitation at Red Feather Lakes, at the same elevation and $15 \mathrm{~km}$ to the southwest of the study site, is approximately $410 \mathrm{~mm}$. The long-term average precipitation during the May through September period is about 240 $\mathrm{mm}$. During the May through September period in 1995 when this study was conducted, the weather station in Red Feather Lakes recorded nearly $360 \mathrm{~mm}$ of precipitation (NOAA 1995).

Research paddocks (approximately 0.25 ha) were located in 1994 within the large grazing exclosures. Paddocks were selected based on the proportion of willow canopy coverage (about 1/3 of total plant cover) and similarity of the understory vegetation. There were a total of 12 research paddocks, with 3 paddocks (i.e., 3 replications) being grazed during each of 4 grazing periods. The grazing period and order in which each of the 12 paddocks were used was chosen at random. The grazing periods were spring, early-summer, late-summer, and fall. These grazing periods corresponded to the following phenological stages of planeleaf willow (Salix planifolia Pursh.): flowering and leaf emergence, full leaf expansion, mature leaf clusters, and leaf senescence.

The understory vegetation in the paddocks was a tall sedge (Carex spp.) dominated community. Water sedge ( $C$. aquatilis Wahlenberg) and beaked sedge (C. utriculata Boott) were dominant species, while Nebraska sedge (C. nebrascensis Dewey) and Baltic rush (Juncus arcticus Willd.) were found on drier microsites. Common grasses found on the study site included bluejoint reedgrass (Calamagrostis canadensis (Michaux) $P$. Beauvois), bluegrass (Poa spp.), tufted hairgrass (Deschampsia caespitosa (L.) $P$. Beauvois), and common Timothy (Phleum pratense L.). Forbs were a relatively minor component of the vegetation, with cinquefoil (Potentilla spp.) and white clover (Trifolium repens $\mathrm{L}$.) as the most common species. Shrubby cinquefoil (Pentaphylloides floribunda (Pursh) Love) was the only common shrub within the understory. Skunkbrush (Rhus aromatica Aiton subsp. trilobata Nuttall) and raspberry (Rubus spp.) were occasionally found in the research paddocks.

The overstory vegetation of the study area was dominated by several willow species. These included planeleaf willow, Geyer willow (Salix geyeriana Andersson), yellow willow ( $S$. lutea Nuttall), sandbar willow ( $S$. exigua Nuttall), and peach-leaved willow ( $S$. amygdaloides Andersson). An occasional lodgepole pine (Pinus contorta Douglas subsp. latifolia) was found on the driest microsites.

Vegetation biomass at the beginning of each grazing period was determined by clipping to ground level ten, $0.25 \mathrm{~m}^{2}$ quadrats located along 4 random transects in each grazing paddock. Available biomass of current year's growth (CYG) of all willows within the $0.25 \mathrm{~m}^{2}$ quadrats was also collected. Available willow biomass was defined as CYG rooted within the $0.25 \mathrm{~m}^{2}$ quadrats that was within $2 \mathrm{~m}$ of ground level (i.e., height to which steers browsed). The CYG unavailable to the steers was not sampled. All vegetation samples were oven-dried at $55^{\circ} \mathrm{C}$ for 48 hours to obtain dry weights.

The botanical composition of cattle diets was sampled during the 4 grazing periods in 1995 using five, $450 \mathrm{~kg}$, esophageally fistulated Holstein steers in each research paddock. It has been determined that esophageally fistulated animals give the most reliable estimate of diet composition of any of the common methods used (Laycock et al. 1972, Holechek et al. 1982). Prior to diet sample collection, the experimental animals were allowed to graze riparian areas adjacent to the research paddocks, so that they could become familiar with the vegetation found on the site. Additionally, the same experimental animals were used the previous year for a related study at Sheep Creek.

Diet samples were collected during each grazing period at initial use, low, moderate, and high levels of herbaceous utilization. The level of herbaceous utilization was determined using stubble height measurements and a photographic utilization guide developed by Kinney and Clary (1994). Stubble height measurements were taken every $0.5 \mathrm{~m}$ along 5 randomly located $10 \mathrm{~m}$ transects in each paddock. Herbaceous species that were measured for stubble height included water sedge, beaked sedge, bluejoint reedgrass, and Kentucky bluegrass (Poa pratensis L.). Collectively, these 4 species accounted for approximately $75 \%$ of the herbaceous biomass within the grazing paddocks. The individual plant of the aforementioned species closest to the sample point along the transect line was measured for residual stubble height. The mean stubble height was used to determine the level of utilization for each species. A weighted average herbaceous utilization level for the paddock was then calculated. Stubble height measurements were taken prior to sampling steer diets to insure that appropriate utilization levels were obtained.

At initial use, the steers were introduced to the paddocks and a diet sample taken. Following the sample period, steers were allowed to graze the paddock until herbaceous utilization was approximately $15 \%$ (i.e., a low level of use). Animals were penned (i.e., fasted) overnight and the next morning diet samples were again collected from each steer. After the second sampling period, the steers were allowed to graze the paddock until herbaceous utilization was approximately $35 \%$ (i.e., a moderate level of use). The following morning diet samples were again collected from each steer. The final diet sample was collected after the steers were allowed to graze the 
paddock until a high level of use (> 50\% utilization) had occurred. This sampling procedure resulted in 4 or 5 days of consecutive grazing for each research paddock. This procedure also minimized the effects of trampling and soiling on steer diet selection.

Diet samples were collected between 0700 and 1000 hours of each day that diet samples were collected. The diet sampling period for each steer during each collection period was approximately 20 minutes. This was the maximum time available to insure that the fistulas did not shrink and become irritated when the canula was reinserted.

Diet samples were washed, refrigerated, and frozen as soon as possible after collection. The frozen diet samples were then processed and slides prepared following procedures outlined by Sparks and Malechek (1968). Botanical composition of the diet samples was determined using the microhistological technique of Theurer et al. (1976).

Data were analyzed using the MIXED procedure of the Statistical Analysis System (SAS) with a factorial arrangement of treatments within a completely randomized design (SAS 1990). The fixed effects tested were 4 periods of grazing (i.e., spring, early summer, late summer, and fall), 4 levels of utilization (stubble height), and the grazing period $\mathrm{x}$ utilization interaction. The replication and steer effects and their associated interactions were treated as random effects ( $P$. Chapman, pers. communication). Significance was tested at the $\mathrm{P}<$ 0.10 level of significance.

\section{Results and Discussion}

\section{Available Biomass}

Current year's herbaceous and woody species biomass available to steers for consumption during the spring grazing period averaged $1129 \mathrm{~kg} / \mathrm{ha}$. Available biomass increased by approximately $50 \%$ to $1657 \mathrm{~kg} / \mathrm{ha}$ during the early-summer grazing period, and was nearly double the initial value $(2852 \mathrm{~kg} / \mathrm{ha})$ by late-summer.
During the fall grazing period, available biomass was estimated to be $3988 \mathrm{~kg} / \mathrm{ha}$ (Table 1).

During the 1995 growing season, the Sheep Creek study site received nearly $50 \%$ more precipitation than the long-term average. All of the research paddocks were in streamside locations dominated by tall sedges and had a high water table. Because of naturally high soil moisture levels on the site, excess precipitation in 1995 had minimal effects on biomass production. In an earlier study conducted at Sheep Creek, Schulz and Leininger (1990) reported that peak standing biomass was $2410 \mathrm{~kg} / \mathrm{ha}$ averaged over 2 years of their study. However, they sampled drier sites which were not dominated by tall sedges, and willows were not included in their biomass values. On a similar study site in California, Huber et. al (1995) reported $2669 \mathrm{~kg} / \mathrm{ha}$ of herbaceous biomass for streamside locations averaged over 2 years of their study.

\section{Willow in Steer Diets}

A significant grazing period $\mathrm{x}$ utilization level $(P<0.01)$ interaction on the percentage of willows in steer diets was caused by higher willow consumption at moderate to high forage utilization levels late in the growing season (late-summer, fall) rather than earlier in the season. During the spring grazing period, willow consumption did not increase $(P>0.10)$ compared to initial use until herbaceous forage stubble height had reached $10 \mathrm{~cm}$ (Table 2). Willows comprised only $1 \%$ of steer diets at initial use and gradually increased to $24 \%$ of diets at a high level of utilization.

Willow consumption increased $(\mathrm{P}<$ 0.10 ) by $19 \%$ during the early-summer grazing period between initial use and the low level of utilization. This increase occurred at a residual stubble height of 18 $\mathrm{cm}$ (Table 2). Willow consumption by steers remained similar $(P>0.10)$ throughout the rest of the early-summer grazing period. Willows comprised between 2 and $34 \%$ of steer diets during the early-summer grazing period.

During the late-summer grazing period the percentage of willows in steer diets did not increase $(\mathrm{P}<0.10)$ until a moderate level of use had occurred (Table 2). This increase occurred when residual stubble heights reached $22 \mathrm{~cm}$. The percentage of willows in steer diets increased $(\mathrm{P}<0.10)$ again between moderate and high levels of utilization when residual stubble heights were measured at $12 \mathrm{~cm}$.

During the fall grazing period, willows comprised from $4 \%$ to $48 \%$ of steer diets as residual stubble heights decreased from initial use to a high level of utilization (Table 2). The percentage of willow in steer diets increased between initial use and a low level of utilization when residual stubble height was reduced from 65 $\mathrm{cm}$ to $37 \mathrm{~cm}$. Another increase in willow consumption occurred at a high level of use when herbaceous stubble height was reduced to $15 \mathrm{~cm}$.

There is little empirical evidence in the literature that suggests willow consumption increases as the grazing season progresses or as the level of herbaceous use increases. In a related study to determine cattle diet preferences at the Sheep Creek study site, Evans (2001) found that willows were avoided throughout the study period. He noted that willow species were only about $15 \%$ as common in steer diets as they were in the available forage. Roath and Krueger (1982) reported that shrub use in an Oregon riparian community increased as the grazing season progressed. They found that shrub utilization was very low during the first 4 weeks of the grazing season. They felt that shrub consumption increased as the grazing season progressed because herbaceous vegetation was maturing and becoming less palatable. Similarly, Kauffman et al. (1983) observed that browsing by cattle increased throughout the growing season. However, these authors felt that increased browse consumption was because current utilization levels limited the availability of preferred herbaceous forage. In addition, the authors noted that a shift to shrub use later in the growing season generally did not occur if $10 \mathrm{~cm}$ of herbaceous stubble remained. The authors also indicated that

Table 1. Mean available aboveground biomass $\left(\mathrm{kg}^{\circ} \mathrm{ha}^{-1}\right)$ before grazing during 4 grazing periods in 1995 for a montane riparian community.

\begin{tabular}{|c|c|c|c|c|c|c|c|c|c|c|c|c|}
\hline \multirow[t]{2}{*}{ Grazing Period } & \multicolumn{2}{|c|}{ Willows } & \multicolumn{2}{|c|}{ Sedges } & \multicolumn{2}{|c|}{ Grasses \& Rushes } & \multicolumn{2}{|c|}{ Eorbs } & \multicolumn{2}{|c|}{ Other Shrubs } & \multicolumn{2}{|c|}{ Total } \\
\hline & $\overline{\text { Biomass }}$ & $\mathrm{SE}$ & Biomass & $\mathrm{SE}$ & Biomass & $\overline{S E}$ & Biomass & SE & Biomass & $\mathrm{SE}$ & $\overline{\text { Biomsss }}$ & $\mathrm{SE}$ \\
\hline & & & & & & $\left.\mathrm{ha}^{-1}\right)$ & & & & & & \\
\hline Spring & $138^{\mathrm{al}}$ & 44 & $369^{c}$ & 66 & $152 c$ & 44 & $8^{c}$ & 4 & $463^{a}$ & 453 & $1129^{d}$ & 593 \\
\hline Early summer & $293^{a}$ & 152 & $759^{\mathrm{bc}}$ & 145 & $495^{b c}$ & 110 & $84^{\mathrm{bc}}$ & 38 & $26^{\mathrm{a}}$ & 21 & $1657^{c}$ & 89 \\
\hline Late summer & $174^{a}$ & 74 & $1303^{b}$ & 360 & $1114^{\mathrm{a}}$ & 272 & $185^{\mathrm{ab}}$ & 51 & $75^{\mathrm{a}}$ & 75 & $2852^{b}$ & 41 \\
\hline Fall & $515^{\mathrm{a}}$ & 301 & $2329^{a}$ & 502 & $828^{\mathrm{ab}}$ & 277 & $104^{\mathrm{bc}}$ & 56 & $213^{a}$ & 151 & $3988^{a}$ & 407 \\
\hline
\end{tabular}

${ }^{1}$ Means within a column with different superscripts are significantly different at $\mathrm{P}<0.10$. 
Table 2. Botanical composition (\%) of steer diets by grazing period and residual stubble height (cm) in 1995 for a montane riparian community grazed to low ( $15 \%)$, moderate $(35 \%)$, or high $(50 \%)$ levels of utilization.

\begin{tabular}{|c|c|c|c|c|c|c|c|c|c|c|c|c|c|c|c|c|}
\hline \multirow[b]{2}{*}{$\begin{array}{l}\text { Class of } \\
\text { Plants }\end{array}$} & \multicolumn{4}{|c|}{ Spring } & \multicolumn{4}{|c|}{ Early-summer } & \multicolumn{4}{|c|}{ Late-summer } & \multicolumn{4}{|c|}{ Fall } \\
\hline & $\begin{array}{l}\text { Initial } \\
\text { Use }\end{array}$ & Low & Mod. & High & $\begin{array}{l}\text { Initial } \\
\text { Use }\end{array}$ & Low & Mod. & High & $\begin{array}{l}\text { Initial } \\
\text { Use }\end{array}$ & Low & Mod. & High & $\begin{array}{l}\text { Initial } \\
\text { Use }\end{array}$ & Low & Mod. & High \\
\hline $\begin{array}{l}\text { Sadges/ } \\
\text { Rushes (\%) } \\
\mathrm{SE}^{2}\end{array}$ & $\begin{array}{c}88.9^{\mathrm{al}} \\
3.2\end{array}$ & $\begin{array}{r}83.9^{\mathrm{a}} \\
3.2\end{array}$ & $\begin{array}{r}66.6^{\mathrm{b}} \\
3.5\end{array}$ & $\begin{array}{c}72.3^{\mathrm{b}} \\
5.7^{2}\end{array}$ & $\begin{array}{c}94.0^{\mathrm{d}} \\
0.8\end{array}$ & $\begin{array}{c}69.1^{\mathrm{e}} \\
4.0\end{array}$ & $\begin{array}{c}52.8^{f} \\
4.8\end{array}$ & $\begin{array}{c}50.3^{f} \\
5.3\end{array}$ & $\begin{array}{c}68.9^{\mathrm{h}} \\
5.2\end{array}$ & $\begin{array}{c}86.7^{\mathrm{j}} \\
1.8\end{array}$ & $\begin{array}{c}55.6^{\mathrm{k}} \\
4.6\end{array}$ & $\begin{array}{c}48.3^{k} \\
4.8\end{array}$ & $\begin{array}{c}88.3^{\mathrm{m}} \\
1.9\end{array}$ & $\begin{array}{c}72.5^{n} \\
3.8\end{array}$ & $\begin{array}{c}69.6^{n} \\
4.5\end{array}$ & $\begin{array}{c}37.8^{\circ} \\
4.8\end{array}$ \\
\hline $\begin{array}{l}\text { Grasses (\%) } \\
\mathrm{SE}\end{array}$ & $\begin{array}{l}9.7^{\mathrm{b}} \\
3.3\end{array}$ & $\begin{array}{c}10.0^{\mathrm{b}} \\
2.9\end{array}$ & $\begin{array}{c}16.2^{\mathrm{a}} \\
1.5\end{array}$ & $\begin{array}{l}2.8^{\mathrm{b}} \\
0.7^{2}\end{array}$ & $\begin{array}{l}2.7^{f} \\
0.6\end{array}$ & $\begin{array}{l}7.4^{\mathrm{e}} \\
1.1\end{array}$ & $\begin{array}{c}15.8^{\mathrm{d}} \\
2.0\end{array}$ & $\begin{array}{c}13.7^{\mathrm{d}} \\
2.1\end{array}$ & $\begin{array}{l}9.5^{h} \\
1.6\end{array}$ & $\begin{array}{l}9.1^{h} \\
1.6\end{array}$ & $\begin{array}{c}10.9^{h} \\
2.1\end{array}$ & $\begin{array}{r}11.6^{\mathrm{h}} \\
1.8\end{array}$ & $\begin{array}{l}5.0^{\mathrm{k}} \\
1.3\end{array}$ & $\begin{array}{l}6.1^{k} \\
1.4\end{array}$ & $\begin{array}{l}4.2^{k} \\
1.1\end{array}$ & $\begin{array}{l}4.2^{k} \\
0.9\end{array}$ \\
\hline $\begin{array}{l}\text { Folbs (\%) } \\
\text { SE }\end{array}$ & $\begin{array}{l}0.2^{\mathrm{a}} \\
0.1\end{array}$ & $\begin{array}{l}0.3^{\mathrm{a}} \\
0.1\end{array}$ & $\begin{array}{l}0.7^{\mathrm{a}} \\
0.2\end{array}$ & $\begin{array}{l}0^{\mathrm{a}} \\
0\end{array}$ & $\begin{array}{l}1.3^{\mathrm{c}} \\
0.4\end{array}$ & $\begin{array}{l}1.5^{\mathrm{c}} \\
0.7^{2}\end{array}$ & $\begin{array}{l}1.8^{\mathrm{c}} \\
0.9\end{array}$ & $\begin{array}{l}1.8^{\mathrm{c}} \\
0.7\end{array}$ & $\begin{array}{r}18.4^{f} \\
3.6\end{array}$ & $\begin{array}{l}2.7^{\mathfrak{g}} \\
0.6\end{array}$ & $\begin{array}{l}8.3^{g} \\
2.9\end{array}$ & $\begin{array}{l}5.4^{\mathrm{g}} \\
1.5\end{array}$ & $\begin{array}{l}2.6^{j} \\
1.2\end{array}$ & $\begin{array}{l}0.9^{j} \\
0.3\end{array}$ & $\begin{array}{l}0.6^{\mathrm{j}} \\
0.2\end{array}$ & $\begin{array}{c}10.4^{k} \\
4.1\end{array}$ \\
\hline $\begin{array}{l}\text { Willow (\%) } \\
\text { SE }\end{array}$ & $\begin{array}{l}1.2^{\mathrm{c}} \\
0.5\end{array}$ & $\begin{array}{l}5.7^{\mathrm{bc}} \\
1.6\end{array}$ & $\begin{array}{l}6.9^{\mathrm{ab}} \\
1.7\end{array}$ & $\begin{array}{c}24.2^{\mathrm{a}} \\
5.2\end{array}$ & $\begin{array}{l}1.9^{g} \\
0.6\end{array}$ & $\begin{array}{r}21.1^{f} \\
4.7\end{array}$ & $\begin{array}{r}28.7^{f} \\
5.4\end{array}$ & $\begin{array}{r}34.0^{\mathrm{f}} \\
5.6\end{array}$ & $\begin{array}{l}2.5^{\mathrm{j}} \\
1.0\end{array}$ & $\begin{array}{l}1.4^{\mathrm{j}} \\
0.6\end{array}$ & $\begin{array}{c}25.0^{k} \\
4.6\end{array}$ & $\begin{array}{r}33.1^{1} \\
5.0\end{array}$ & $\begin{array}{l}3.7^{\mathrm{n}} \\
0.8\end{array}$ & $\begin{array}{c}20.5^{\circ} \\
3.9\end{array}$ & $\begin{array}{c}25.5^{\circ} \\
4.7\end{array}$ & $\begin{array}{c}47.5^{\mathrm{p}} \\
5.4\end{array}$ \\
\hline $\begin{array}{l}\text { Other } \\
\text { Browse (\%) } \\
\text { SE }\end{array}$ & $\begin{array}{l}0.1^{c} \\
0.1^{\circ}\end{array}$ & $\begin{array}{l}0.1^{\mathrm{c}} \\
0.1^{1}\end{array}$ & $\begin{array}{l}9.6^{\mathrm{a}} \\
3.0\end{array}$ & $\begin{array}{l}0.7^{b} \\
0.3\end{array}$ & $\begin{array}{l}0^{e} \\
0\end{array}$ & $\begin{array}{l}0.9^{e} \\
0.4\end{array}$ & $\begin{array}{l}0.8^{\mathrm{e}} \\
0.3\end{array}$ & $\begin{array}{l}0.2^{\mathrm{e}} \\
0.1\end{array}$ & $\begin{array}{l}0.8^{h} \\
0.3\end{array}$ & $\begin{array}{l}0.1^{h} \\
0.1^{4}\end{array}$ & $\begin{array}{l}0.3^{\mathrm{h}} \\
0.1\end{array}$ & $\begin{array}{l}1.6^{\mathrm{g}} \\
0.7\end{array}$ & $\begin{array}{l}0.4^{j} \\
0.2^{j}\end{array}$ & $\begin{array}{l}0.1^{\mathrm{j}} \\
0.1^{1}\end{array}$ & $\begin{array}{l}0^{\mathrm{j}} \\
0\end{array}$ & $\begin{array}{l}0.4^{j} \\
0.2^{j}\end{array}$ \\
\hline $\begin{array}{l}\text { Stubble Height }(\mathrm{cm}) \\
\text { SE }\end{array}$ & $\begin{array}{r}18.4 \\
3.7\end{array}$ & $\begin{array}{r}14.7 \\
1.3\end{array}$ & $\begin{array}{r}10.2 \\
0.4\end{array}$ & $\begin{array}{l}8.8 \\
0.6\end{array}$ & $\begin{array}{r}39.8 \\
2.0\end{array}$ & $\begin{array}{r}18.3 \\
0.3\end{array}$ & $\begin{array}{r}15.3 \\
1.3\end{array}$ & $\begin{array}{r}11.7 \\
0.4\end{array}$ & $\begin{array}{l}56.2 \\
13.1\end{array}$ & $\begin{array}{r}31.2 \\
6.2\end{array}$ & $\begin{array}{r}22.4 \\
5.5\end{array}$ & $\begin{array}{r}12.0 \\
3.0\end{array}$ & $\begin{array}{r}65.3 \\
4.2\end{array}$ & $\begin{array}{r}36.7 \\
5.4\end{array}$ & $\begin{array}{r}22.2 \\
2.9\end{array}$ & $\begin{array}{r}14.7 \\
1.6\end{array}$ \\
\hline
\end{tabular}

Means within a row and in the same grazing period with different superscripts are significantly different at $P<0.10$.

'Standard error of the mean.

highly palatable shrubs may be utilized before the $10 \mathrm{~cm}$ stubble height was reached. Observations by Kovalchik and Elmore (1992) suggested that mid- to lateseason shrub use would begin at about 10 to $15 \mathrm{~cm}$ of forage stubble height, and browsing would continue to increase until cattle would browse all the willows they could reach when herbaceous stubble heights were reduced to less than $5 \mathrm{~cm}$ in height. Hall and Bryant (1995) stated that managers should assume that shrub use will occur at stubble heights below $8 \mathrm{~cm}$, or as palatable forages decline in quality. Meyers (1989) observed that the utilization of riparian woody species by cattle increased in late-August and remained high through the fall period. He believed that the observed increase in browse utilization late in the growing season was in response to declining herbaceous forage availability. In addition, Meyers reported that stubble heights greater than $15 \mathrm{~cm}$ might be necessary to protect riparian ecosystem function. Similarly, Clary (1999) reported that species richness and streambank stability increased, stream channels narrowed, and streamside willow communities increased when an Idaho mountain meadow was grazed to a $14 \mathrm{~cm}$ streamside stubble height for 10 years.

The data we collected on willow consumption agreed with the recommendations of Meyers (1989) and the observations reported by Kauffman et al. (1983). Willows comprised an important portion of steer diets in our study at high levels of herbaceous species utilization as soon as willow leaves were fully expanded. This suggested that shifts in cattle diet selection might occur much earlier in the growing season than previously expected. During the spring grazing period, willow consumption increased as stubble heights approached the $10-15 \mathrm{~cm}$ guideline proposed by Clary and Webster (1989). In contrast, willow consumption increased during the early-summer, late-summer, and fall grazing periods when stubble heights reached 18,22 , and $37 \mathrm{~cm}$, respectively. This suggests that higher residual stubble heights must be maintained late in the season to minimize willow consumption when grazing tall sedge communities.

At the Sheep Creek study site, utilization levels of herbaceous species averaged approximately $40 \%$ at a $15 \mathrm{~cm}$ stubble height when averaged across all grazing seasons. Clary and Webster (1989) also reported data that related stubble height to herbaceous utilization. Their data indicated that utilization levels of $24-32 \%$ were obtained when herbaceous stubble heights were $15 \mathrm{~cm}$. These differences illustrate that the level of utilization at a specific stubble height will change, depending on the herbaceous species present and specific site characteristics.

\section{Sedges and Rushes in Steer Diets}

A strong $(P<0.001)$ grazing period $x$ utilization interaction existed for sedges and rushes in steer diets. Sedges and rushes made up between $38-94 \%$ of diet composition (Table 2) and generally decreased in steer diets within each grazing period as residual stubble heights decreased. However, the residual stubble height at which significant $(P<0.10)$ decreases in sedge and rush consumption occurred changed as the growing season progressed. During the spring grazing period the sharpest decline $(P<0.10)$ in sedge and rush consumption occurred between low and moderate levels of utilization as residual stubble heights approached 10 $\mathrm{cm}$. The proportion of sedges and rushes in steer diets decreased by $17 \%$ between these 2 sampling periods (Table 2). Sedge and rush consumption declined $(\mathrm{P}<0.10)$ by $25 \%$ between initial use and a low level of utilization during the early-summer grazing period and by $16 \%$ between low and moderate levels of utilization. Residual stubble heights were 18 and 15 $\mathrm{cm}$, respectively (Table 2 ). During the late-summer grazing period, sedge and rush consumption increased $(\mathrm{P}<0.10)$ by $18 \%$ between initial use and a low level of use as the residual stubble height approached $30 \mathrm{~cm}$. As residual stubble heights surpassed $22 \mathrm{~cm}$ between low and moderate levels of utilization, sedge and rush consumption declined $(P<0.10)$ and remained similar at a high level of utilization (Table 2). Sedge and rush composition in steer diets during the fall grazing period decreased $(\mathrm{P}<0.10)$ between initial use and a low level of utilization and again between moderate and high levels of utilization. Sedges and rushes in steer diets declined by 16 and $32 \%$ as residual stubble heights reached 37 and $15 \mathrm{~cm}$, respectively. With the exception of the spring grazing period, these declines in sedge and rush composition in steer diets can be attributed to similar increases in willow consumption by the steers (Table 2).

Huber et al. (1995) reported that sedges and rushes were the 2 most common components of cattle diets while grazing a riparian community in California. They also noted that grass-like species increased 
in cattle diets throughout the growing season. Huber et al. (1995) attributed this shift in diet preference to decreased palatability of grasses as the grazing season progressed. Similarly, Evans (2001) reported that steers showed a preference for consuming sedges and rushes in his study conducted on the same study site as our investigation. Our results support these previous findings, but also suggest that sedges and rushes make up a smaller proportion of steer diets as residual stubble heights decrease regardless of grazing period. As the growing season progressed and as residual stubble heights decreased, the available herbaceous forage became more lignified and fibrous. Heady and Child (1994) reported that leaves, flowers, and seeds are generally more palatable because of these chemical differences. Our analyses revealed opposite responses for the grazing period $\mathrm{x}$ utilizations interactions for sedges and rushes and willows in steer diets. As sedge and rush consumption declined because of decreased palatability, willow consumption generally increased.

\section{Grasses in Steer Diets}

Grasses in steer diets also exhibited a grazing period $x$ utilization interaction ( $P$ $<0.10)$. The percentage of grasses in steer diets was similar $(\mathrm{P}>0.10)$ as stubble heights decreased during the late-summer and fall grazing periods. Grasses comprised between $4 \%$ and $19 \%$ of steer diets during these 2 grazing periods (Table 2). However, there were some differences in grass consumption among levels of use as residual stubble heights decreased in the spring and early-summer grazing periods.

During the spring grazing period grass consumption by the steers increased $(\mathrm{P}<$ 0.10 ) between low and moderate levels of utilization when residual stubble heights reached $10 \mathrm{~cm}$ (Table 2). Grasses in steer diets then decreased $(\mathrm{P}<0.10)$ between moderate and high levels of utilization as residual stubble heights continued to decline. The percentage of grasses in steer diets during this grazing period was the lowest at a high level of utilization.

Percentage of grasses in steer diets generally increased as residual stubble heights were reduced during the early-summer grazing period. Significant increases $(\mathrm{P}<$ 0.10 ) in grass consumption occurred between initial use and a low level of utilization, and again between low and moderate levels of utilization. These increases occurred at residual stubble heights of 18 and $15 \mathrm{~cm}$, respectively (Table 1).
Evans (2001) reported that steers showed neutral preference or avoided grasses, depending upon grass species. Tufted hairgrass was the only grass that was preferred by steers in his study. Huber et al. (1995) detected no significant differences in cattle diet selection between low and moderately stocked pastures. Although diet selection was similar, these researchers reported that grazing behavior and area of use was altered by the level of use. In addition, Huber et al. (1995) reported that grass consumption declined throughout the growing season. They attributed their results to the effects of advancing plant maturity. In contrast, Holechek et al. (1982) found that cattle grazing a riparian meadow in Oregon had increased consumption of grasses as the growing season progressed. However, they noted that grass regrowth was available to the experimental animals during the fall of each year of their study, which contributed to these diets.

In our study, grass consumption remained relatively constant throughout the growing season with less grasses being consumed during the fall grazing period. These results follow those of Huber et al. (1995) more closely than those of Holechek et al. (1982). In their study in Oregon, Holechek et al. (1982) sampled cattle diets over a 28 -day period. In our study, steer diets were sampled over a 4 or 5-day period in each paddock during each of 4 periods, and previously sampled paddocks were not revisited. This difference in sampling techniques may help explain the differences in dietary consumption.

\section{Forbs in Steer Diets}

Similar to all other diet classes, the grazing period $\mathrm{x}$ utilization interaction was significant $(P<0.001)$ for forbs in steer diets. During the spring and early-summer grazing periods, the percentage of forbs in steer diets was similar $(\mathrm{P}>0.10)$ as residual stubble heights became shorter. During the late-summer grazing period, however, forbs in steer diets was highest at initial use (Table 2), making up $18 \%$ of steer diets. Forbs made up a higher $(\mathrm{P}<0.10)$ percentage of steer diets at this level of use when compared with low, moderate and high levels of utilization. The percentage of forbs in steer diets was similar ( $P$ > 0.10 ) among all other levels of herbaceous utilization. A different trend was identified for the fall grazing period. At a high level of utilization, when residual stubble heights were near $15 \mathrm{~cm}$, forbs made up a higher $(P<0.10)$ percentage of steer diets when compared with the percentage of forbs in steer diets at taller residual stubble heights. There were no differences in the amount of forbs in steer diets among the other 3 levels of use.

Our findings do not agree with those of Holechek et al. (1982) who reported that cattle preference for forbs was greatest early in the growing season and shifted to grasses as the season progressed. Huber et al. (1995) also reported that forb consumption by cattle grazing a riparian zone decreased as the growing season progressed. Forb consumption by steers in this present study closely followed the trend of forb availability. Available forb biomass was greatest during the late-summer grazing period when compared with the other 3 grazing seasons (Table 1). Forb biomass averaged only $8 \mathrm{~kg} \mathrm{ha}^{-1}$ during the spring grazing period, while during the early-summer grazing period forb biomass available to steers increased to $84 \mathrm{~kg} \mathrm{ha}$ (Table 1). Forb biomass during the fall grazing period was $104 \mathrm{~kg} \mathrm{ha}^{-1}$. Holechek et al. (1982) reported that livestock were very opportunistic in their grazing habits. Our results supported this finding, as forb consumption followed forb availability.

\section{Other Browse in Steer Diets}

Browse species, other than willows, available to the steers were uncommon in our paddocks. When available, other browse species consisted of lodgepole pine, shrubby cinquefoil, skunkbrush, and raspberry. Although uncommon in the research paddocks, our analyses revealed a grazing period $\mathrm{x}$ utilization interaction. Other browse generally made up less than $1 \%$ of steer diets (Table 2). However, steer diets did contain a higher percentage $(\mathrm{P}<$ 0.10 ) of other browse during the spring season at moderate and high levels of utilization when compared to the other levels of use throughout the same grazing period. Other browse also made up a higher percentage $(P<0.10)$ of steer diets at a high level of utilization during the late-summer grazing period when compared to other levels of use during the same grazing period (Table 2). It appears that the steers were opportunistic in their consumption of other browse species. This was also the case with forb consumption in our study and agrees with the findings of Holechek et al. (1982).

Although this was a 1 year study, important relationships between diet composition and residual stubble height (herbaceous utilization) were identified. The information reported in this paper should be widely applicable throughout the West. 
Riparian communities similar to the Sheep Creek study area can be found throughout much of the western United States (Costello 1944, Kauffman et al. 1985, Marlow and Pogacnik 1985, Platts and Nelson 1985, Ratliff and Westfall 1987, Clary 1995, Huber et al. 1995).

\section{Management Implications}

Protection of the ecological integrity of riparian areas is a complicated issue that many natural resource managers must address (Clary and Leininger 2000). Although grazing activity has the potential to have dramatic impacts on riparian woody vegetation, our data suggest that through careful control of timing of use and the level of herbaceous utilization (by monitoring residual stubble heights) the consumption of willows by livestock in riparian communities can be minimized.

Our data suggest that the 10 to $15 \mathrm{~cm}$ stubble height guideline currently in use by several natural resource agencies was adequate for protection of willows during spring and early-summer grazing. However, stubble heights may need to be maintained near $20 \mathrm{~cm}$ to minimize willow consumption in tall sedge communities during the late-summer and fall grazing periods. These stubble height guidelines should only be used on sites with similar vegetation communities and biomass production potentials.

The 2 most important factors to consider when developing grazing plans for riparian areas are the season of use and the intensity of use. Krueger (1996) indicated that the season of use was far more important than the intensity of use. However, he noted that even relatively light levels of use could have significant effects on the growth of some shrubs. In contrast, Clary and Webster (1989) stated that the intensity of use was the most important consideration when grazing plans for riparian areas are developed. The results of our research showed important interactions between period of use within a growing season and level of utilization on use of both willow and herbaceous species. Although willows were preferred more by steers in late-summer and fall, the amount of their use was directly related to the amount of herbaceous forage that had been previously removed.

This investigation has provided managers with information that will help them to limit the level of willow defoliation. However, information relating site characteristics to response to grazing management and site recovery is limited. Future research should focus on these factors, as well as mechanisms that affect recovery.

\section{Literature Cited}

Armour, C., D. Duff, and W. Elmore. 1994. The effects of livestock grazing on western riparian and stream ecology. Fisheries 19:9-12.

Baker, B.W. and W.C. Leininger. 1992. Research needs for riparian management. p. 122-132. In: Proc. Colorado Riparian Assoc. Fourth Ann. Conv., Nov. 4-6, Steamboat Springs, Colo.

Belsky, A.J., A. Matzke, and S. Uselman. 1999. Survey of livestock influences on stream and riparian ecosystems in the western United States. J. Soil Water Cons. 54:419-431.

Bryant, L.D. 1982. Response of livestock to riparian zone exclusion. J. Range Manage. 35:780-785.

Chaney, E., W. Elmore, and W.S. Platts. 1993. Managing change: livestock grazing on western riparian areas. Report prepared for the Environmental Protection Agency. Northwest Resource Information Center. Eagle, Ida.

Clary, W.P. 1995. Vegetation and soil responses to grazing simulation on riparian meadows. J. Range Manage. 48:18-25.

Clary, W.P. 1999. Stream channel and vegetation responses to late spring cattle grazing. J. Range Manage. 52:218-227.

Clary, W.P. and G.D. Booth. 1993. Early season utilization of mountain meadow riparian pastures. J. Range Manage. 46:493-497.

Clary, W. P. and W.C. Leininger, 2000. Stubble height as a tool for management of riparian areas. J. Range Manage. 53:562-573.

Clary, W.P. and B.F. Webster. 1989. Managing grazing of riparian areas in the Intermountain Region. USDA For. Serv. Gen. Tech. Rep. INT-263. $11 \mathrm{p}$.

Costello, D.F. 1944. Important species of the major forage types in Colorado and Wyoming. Ecol. Mon. 14:106-134.

Elmore, W. and R.L. Beschta. 1987. Riparian areas: perceptions in management. Rangelands 9:260-265.

Evans, S.G. 2001. Seasonal diet selection of cattle grazing a montane riparian community. M.S. Thesis, Colorado St. Univ., Fort Collins, Colo.

Hall, F.C. and L. Bryant. 1995. Herbaceous stubble height as a warning of impending cattle grazing damage to riparian areas. USDA For. Gen. Tech. Rep. PNW-GTR-362. 9 p.

Heady, H.F. and R.D. Child. 1994. Rangeland Ecology and Management. Westview Press, Inc., Boulder, Colo.

Holechek, J.L., M. Vavra, and R.D. Pieper. 1982. Botanical composition determination of range herbivore diets: a review. J. Range Manage. 35:309-315.

Huber, S.A., M.B. Judkins, L.J. Krysl, T.J. Svejcar, B.W. Hess, and D.W. Holcombe. 1995. Cattle grazing a riparian mountain meadow: effects of low and moderate stocking density on nutrition, behavior, diet selection, and plant growth response. J. Anim. Sci. 73:3752-3765.
Kauffman, J.B. and W.C. Krueger. 1984. Livestock impacts on riparian ecosystems and streamside management implications...a review. J. Range Manage. 37:430-437.

Kauffman, J.B., W.C. Krueger, and $M$. Vavra. 1983. Effects of late season cattle grazing on riparian plant communities. J. Range Manage. 36:685-691.

Kauffman, J.B., W.C. Krueger, and M. Vavra. 1985. Ecology and plant communities of the riparian area associated with Catherine Creek in northeastern Oregon. Oregon Agr. Exp. Sta. Tech. Bull. 147. Corvallis, Ore.

Kinney, J.W. and W.P. Clary. 1994. A photographic utilization guide for key riparian graminoids. USDA For. Serv. Gen. Tech. Rep. INT-308. 14 p.

Kovalchik, B.L. and W. Elmore. 1992. Effects of cattle grazing systems on willowdominated plant associations in central Oregon, p. 111-119. In: W.P. Clary, E.D. McArthur, D. Bedunah, and C.L. Wambolt (comps.) Proceedings-symposium on ecology and management of riparian shrub communities. USDA For. Serv. Gen. Tech. Rep. INT-289.

Krueger, W.C. 1996. Developing an effective grazing strategy for riparian vegetation. p. 15-22. In: Livestock management in grazed watersheds-a review of practices that protect water quality. Univ. Calif. Davis, Univ. Calif. Agr. Issues Center. Publ. 3381.

Lay cock, W.A., H. Buchanan, and W.C. Krueger. 1972. Three methods of determining diet, utilization, and trampling damage on sheep ranges. J. Range Manage. 25:352-356.

Leonard, S., G. Kinch, V. Elsbernd, M. Borman, and S. Swanson. 1997. Riparian management - grazing management for riparian-wetland areas. USDI Bureau of Land Manage. Tech Ref. 1737-14, Denver, Colo.

Marlow, C.B. and T.M. Pogacnik. 1985. Time of grazing and cattle-induced damage to streambanks, p. 279-284. In: R.R. Johnson, C.D. Ziebell, D.R. Patton, P.F. Ffolliott, and R.H. Hamre (tech. coords.) Riparian ecosystems and their management: reconciling conflicting uses: first North American riparian conference. USDA For. Serv. Gen. Tech. Rep. RM-120.

Marlow, C.B. and T.M. Pogacnik. 1986. Cattle feeding and resting patterns in a foothills riparian zone. J. Range Manage. 39:212-216.

Meyers, L.H. 1989. Grazing and riparian management in southwestern Montana. p. 117-120. In: Practical approaches to riparian resource management-an educational workshop, May 8-1 1, 1989, Billings, Mont. BLMMT-PT-89-001-4351.

Mosley, J.C., P.S. Cook, A.J. Griffis, and J. O'Laughlin. 1997. Guidelines for managing cattle grazing in riparian areas to protect water quality: review of research and best management practices policy. Idaho For., Wildl. and Range Policy Analysis Group Rep.15. Idaho For., Wildl., and Range Exp. Sta., Moscow, Ida. 
NOAA (National Oceanic and Atmospheric Administration). 1995. Climatological data. Red Feather Lakes, Colorado, USA. U.S. Dept. of Commerce, Asheville, NC. ISSN 0145-0506.

Pinchak, W.E., M.A. Smith, R.H. Hart, and J.W. Waggoner, Jr. 1991. Beef cattle distribution patterns on foothill range. J. Range Manage. 44:267-275.

Platts, W.S. and R.L. Nelson. 1985. Streamside and upland vegetation use by cattle. Rangelands 7:5-7.

Popolizio, C.A., H. Goetz, and P.L. Chapman. 1994. Short-term response of riparian vegetation to 4 grazing treatments. J. Range Manage. 47:48-53.
Ratliff, R.D. and A.E. Westfall. 1987. Dryyear grazing and Nebraska sedge (Carex nebraskensis). Great Basin Nat. 47:422-426.

Roath, L.R. and W.C. Krueger. 1982. Cattle grazing influence on a mountain riparian zone. J. Range Manage. 35:100-104.

Rosgen, D.L. 1994. A classification of natural rivers. Catena 22:169-199.

SAS. 1990. SAS/STAT User's Guide. Statistical Analysis Systems Institute, Inc., Cary, N.C.

Schulz, T. and W.C. Leininger. 1990. Differences in riparian vegetation structure between grazed areas and exclosures. J. Range Manage. 43:295-299.
Smith, M.A., J.D. Rodgers, J.L. Dodd, and Q.D. Skinner. 1992. Declining forage availability effects on utilization and community selection by cattle. J. Range Manag. 45:391-395.

Sparks, D.R., and J.C. Malechek. 1968. Estimating percentage dry weight in diets using a microscopic technique. J. Range Manage. 21:264-265.

Theurer, C.B., A.L. Lesperance, and J.D. Wallace. 1976. Botanical composition of the diet of livestock grazing native ranges. Univ. Ariz. Agr. Exp. Sta. Bull. 233, Tuscon, Ariz.

USDA SCS (Soil Conservation Service and Forest Service). 1980. Soil survey report. Larimer County Area, Colo. Naz 70 soil series. U.S. Gov't. Print. Off. 239-812/48. Wash., D.C. 